\title{
TVORBA BÁZE ZNALOSTÍ V EXPERTNÍM SYSTÉMU NEST PRO POSOUZENÍ MÍRY ŠTÍHLOSTI VÝROBY
}

\author{
Radim Dolák
}

Klíčová slova:

expertní systémy, NEST, reprezentace znalostí, tvorba báze znalostí, štíhlá výroba

\section{Key words:}

Expert Systems, NEST, knowledge representation, knowledge base creation, Lean Manufacturing

\begin{abstract}
Abstrakt
Tento článek se zabývá tvorbou báze znalostí v expertním systému NEST, který je řazen do skupiny tzv. prázdných expertních systémů. Nejprve je zmíněna oblast expertních systémů včetně výhod a nevýhod těchto systémů. Je uvedeno i jejich možné využití. Dále následuje popis expertního systému NEST a jeho možností způsobu reprezentace znalostí pro tvorbu báze znalostí. Praktická část příspěvku je zaměřena na tvorbu báze znalostí v expertním systému NEST pro posouzení míry štíhlosti výroby. V této části jsou uvedeny př́iklady tvorby báze znalostí pro posouzení míry zavedení principů štíhlé výroby včetně výstupů z NEST editoru, konzultačního modulu a závěrečného vyhodnocení míry štíhlosti výroby expertním systémem.
\end{abstract}

\begin{abstract}
This article deals with the creation of knowledge base in Expert System NEST, which is classified into the group of empty Expert Systems. It will be mention area of Expert Systems, including advantages and disadvantages of these systems. It also indicated their possible use. This is followed by a description of the Expert System NEST and its possibilities of knowledge representation method for creating a knowledge base. The practical part of this paper is focused on creating knowledge base in Expert System NEST for assessing the Lean Manufacturing. This section provides examples of creating a knowledge base for assessing the implementation of the principles of Lean Manufacturing, including output from NEST editor module, consultation module and final evaluation of the degree of Lean Manufacturing by Expert System.
\end{abstract}

\section{Úvod}

V dnešní době globálního tržního prostředí, které se vyznačuje velkou mírou konkurence, nabývají na významu nové metody a principy managementu pro získání konkurenční výhody. Získání konkurenční výhody je v dnešním světě velmi důležité pro přežití firmy na trhu. Jednou z forem získání konkurenční výhody je využití principů štíhlé výroby. Tyto principy se snaží o odstranění všech zbytečných procesů a činností, které nepřinášejí hodnotu pro zákazníka a zisk pro firmu. Snahou je právě naopak zefektivnění a podpora procesů, které firmě hodnotu a zisk přinášejí. Díky expertním systémům lze velmi urychlit proces identifikace štíhlosti dané firmy na základě pravidel obsažených v bázi znalostí expertního systému. Nejprve bude pozornost zaměřena na všeobecné informace o expertních systémech, poté následuje seznámení s expertním systémem NEST, které zahrnuje obecné informace o systému, jeho struktuře, způsobech reprezentace znalostí, syntaxi báze znalostí a také způsobu odvozování na základě pravidel (inferenční mechanismus). V rámci případové studie bude vytvořena báze znalostí, která bude obsahovat pravidla pro určení míry štíhlosti výroby 
dané firmy. Na základě zodpovězení konkrétních otázek, které se týkají výrobní sféry firmy, pak expertní systém pomocí inferenčního mechanismu, odvodí míru štíhlosti firmy.

\section{Expertní systémy}

V této kapitole bude zmíněna definice expertních systémů, jejich struktura, výhody a v neposlední řadě i možnosti jejich využití pro řešení úkolů rozdílné povahy.

„Expertní systém bývá charakterizován jako počítačový program, který simuluje rozhodovací činnost expertů při řešení složitých, úzce problémově zaměřených úloh. Jedná se tedy o systém, který nevyužívá znalostí nabytých vlastní činností, ale využívá znalostí (myšlení a rozhodování) špičkových odborníků v dané oblasti.“ [10]

„Expertní systémy (ESS - Expert Support Systems) imitují konzultaci s expertem před přijetím rozhodnutí tak, aby manažer mohl rady využít před přijetím konečného rozhodnutí.“ [8]

„Expertní systémy se snaží simulovat řešení vzniklých problémů tak, jak by byly řešeny experty v daném oboru. Obsahují bázi znalostí, které jsou získány od expertů, a jsou na ně uplatněna formální logická pravidla, aby je bylo možné využít v počítačových systémech." [5] Tyto systémy jsou často používány pro podporu rozhodování na úrovni vrcholového řízení. V současnosti se jedná spolu s další aplikací umělé inteligence (BI, DSS atd.) o dynamicky se rozvíjející oblast rozvoje informačních a komunikačních technologií, které zásadním faktorem ovlivňují současnou informační společnost.

Expertní systém se člení na následující komponenty:

- báze znalostí,

- inferenční mechanismus,

- I/O rozhraní,

- vysvětlovací modul,

- modul pro akvizici (získávání znalostí).

Expertní systémy mají řadu nesporných výhod pro své praktické uplatnění při řešení expertních rozhodovacích úloh. Níže uvádím nejvíce prezentované výhody těchto systémů:

- schopnost řešit složité problémy,

- dostupnost expertíz a snížené náklady na jejich provedení,

- trvalost a opakovatelnost expertíz,

- uchování znalostí odborníků odcházejících z organizace,

- rozhodování expertního systému neovlivňuje únava, časový stres a jiné faktory,

- expertní systém dokáže svůj výrok jednoznačně zdůvodnit.

Žádný počítačový systém není samozřejmě dokonalý. Nejinak je tomu také u expertních systémů. Expertní systémy je proto nutné považovat za pomocníka manažerského rozhodování. V případě využití v ekonomice by konečné rozhodnutí mělo záviset na daném manažerovi. Expertní systém jen zpracovává informace a dává doporučení, ke kterým dospěl. Dále zmiňuji nevýhody a nedostatky expertních systémů, které je nezbytné brát vždy v úvahu:

- nebezpečí selhání ve změněných podmínkách,

- neschopnost poznat meze své použitelnosti. 
Tvorbu expertních systémů lze rozdělit do několika na sebe navazujících fází. Podle [4] se v procesu tvorby expertního systému vyskytují následující činnosti:

- výběr hardwaru a softwaru,

- návrh uživatelského rozhraní,

- akvizice znalostí (získání a reprezentace znalostí),

- implementace,

- validace a verifikace.

Možnosti využití expertních systémů jsou téměř neomezené. Expertní systémy nacházejí postupně uplatnění v mnoha oborech. Mezi typické oblasti, kde jsou expertní systémy využívány, patří zejména obchod a medicína. Dále tyto systémy našly své uplatnění i v oborech jako je např. strojírenství, doprava nebo školství. V praktické části článku nastíním možnost využití expertního systému pro zjištění míry dosažení štíhlé výroby. Ve své podstatě je hlavním cílem především podpora managementu firmy, který rychle získá přehled o současném stavu z pohledu konceptu štíhlé výroby.

\section{Expertní systém NEST}

Program NEST je prázdný expertní systém, který obsahuje inferenční mechanismus. Prázdné expertní systémy (Expert System Shells) jsou systémy bez báze znalostí. Teprve po vytvoření báze znalostí, která reprezentuje poznatky experta, vzniká funkční plnohodnotný expertní systém. „Prázdný expertní systém je tvořen především inferenčním mechanismem a prostředky pro tvorbu báze znalostí (předdefinované struktury pro ukládání znalostí). Někdy se nabízejí i prostředky pro ladění báze (napřr. syntaktická kontrola pravidel), editory báze nebo prostředky pro tvorbu uživatelského rozhraní pro koncového uživatele.“ [1]

„Expertní systém NEST navazuje na expertní systém SAK (Systém Automatizovaných Konzultací) vyvinutý na VŠE v polovině 80. let. Dědictví svého předchůdce pak NEST dále rozvíjí tak, jak si to vyžádala zkušenost s reálnými aplikacemi systému SAK.“ [11] „Expertní systém NEST poskytuje uživateli grafické rozhraní (GUI) pro: nahrávání existujících bází znalostí, jejich spuštění, nastavení př́stupu zpracování neurčitosti, vedení konzultace (způsobu získávání dat od uživatele), vyhodnocení a doporučení cílového výroku s možností vysvětlení závěrů. NEST je program určený především pro akademické účely, proto také nebyl kladen důraz na vzhled, ale na funkčnost programu zaměřenou na tvorbu znalostní báze, porovnávání výsledků konzultací při volbě různých druhů práce s neurčitostí atp. NEST není komerčním produktem a jeho využití mimo výukové účely je nutno konzultovat s autory." [6]

NEST se skládá z následujících komponent:

- stand-alone version - program pro provádění konzultací,

- editor - editor pro tvorbu a úpravu bází znalostí,

- base convertor - program pro konverzi bází znalostí,

- klient-server version - NEST pro vzdálený přístup - sít'ová verze.

V další části textu uvedu základní způsoby reprezentace znalostí v expertním systému NEST. Znalosti v systému NEST jsou reprezentovány pomocí:

- atributi̊ a od nich odvozených výroků,

- pravidel,

- kontextů,

- integritních omezení. 
Atribut je určité tvrzení, se kterým systém dokáže pracovat. Systém rozlišuje následující typy atributů: binární, nominální jednoduchý, nominální množinový a numerické. „Od atributů se odvozují výroky. Počet možných výroků je dán podle typu atributu. Každý výrok má zadanou váhovou funkci, která převede číselnou hodnotu na váhu. Váhová funkce je zadávána pomocí fuzzy intervalu. Tento interval je určen čtyřmi čísly (fuzzy lower, crisp lower, crisp upper, fuzzy upper). Pokud je číselná hodnota mimo „fuzzy“ hranice, je výsledná váha „FALSE“, pokud je číselná hodnota uvnitř „crisp“ hranic, je výsledná váha „TRUE“. [12] Základní podoba pravidel v NESTu je následující: IF předpoklad THEN závěr 1 [váha 1], ..., závěr n [váha $\mathrm{n}$ ]. Závěr pravidla je tvořen výrokem a vahou, která slouží pro spočítání váhy výroku v závěru.

\section{Tvorba báze znalostí v expertním systému NEST pro posouzení míry štíhlé výroby}

Praktická část tohoto příspěvku se zabývá možností využití expertního systému NEST pro určení míry štíhlosti výroby dané firmy. Náplní kapitoly je především zadávání kritérií pro určení stupně zavedení prvků štíhlé výroby. Závěrem je uveden proces dotazování a vracení výsledků expertním systémem.

Nejdůležitějším faktorem kvality každého expertního systému je kvalitní báze znalostí, která zahrnuje znalosti vyjádřené pomocí různých typů pravidel. Pro získání znalostí je nesmírně důležitá spolupráce znalostního inženýra s expertem pro danou oblast. Zahraniční literatura v oblasti štíhlé výroby (Lean Manufacturing) je rozsáhlá. Informace o zavádění štíhlé výroby lze najít například v následujících publikacích: [2], [3], [9]. Domácí literatura zabývající se problematikou štíhlé výroby není př́liš rozsáhlá. Jednou z mála ucelených publikací, které se zabývají štíhlou výrobou jako součástí štíhlé firmy (Lean Company) je kniha „Štíhlý a inovativní podnik“. [7]

Pro identifikaci míry úrovně štíhlosti firmy je nejprve nutné definovat pravidla pro stupeň zavedení prvků štíhlého podniku. Zde vycházím z knihy „Štíhlý a inovativní podnik“ od autorů Košturiaka a Frolíka. Tabulku autorů „Stupeň zavedení prvků štíhlého podniku“ jsem upravil na tabulku „Stupeň zavedení prvků štíhlé výroby“, která se zabývá pouze prvky štíhlé výroby.

\begin{tabular}{|l|l|l|l|}
\hline Stupeň zavedení prvků štíhlé výroby & neexistuje & zavádí se & funguje \\
\hline TPM & & & \\
\hline $5 S$ & & & \\
\hline Vizuální řízení & & & \\
\hline Systematické zkracování časů na přestavění zařízení & & & \\
\hline Týmová práce & & & \\
\hline Výroba v malých dávkách & & & \\
\hline Synchronizace procesů & & & \\
\hline Program identifikace a odstraňování plýtvání & & & \\
\hline Vývoj výrobků s ohledem na eliminaci plýtvání ve výrobě & & & \\
\hline Spolupráce technické přípravy výroby a výroby nákladů & & & \\
\hline Standardizace procesů & & & \\
\hline Tahové řízení výroby - kanban & & & \\
\hline Výrobní buňky & & & \\
\hline Propojení dodavatelů přímo s výrobou - externí kanban & & & \\
\hline
\end{tabular}

Tabulka 1: Stupeň zavedení prvků štíhlé výroby 
Všechny výše uvedené prvky štíhlé výroby mají za úkol omezit plýtvání ve výrobě, které je hlavním zdrojem neefektivity. Cílem štíhlé výroby je eliminovat všechny nadbytečné procesy, které nepřidávají hodnotu výrobku nebo služby pro zákazníky a vedou pouze k plýtvání cennými zdroji. Tyto základní prvky štíhlé výroby jsou podrobněji popsány v knize „Štíhlý a inovativní podnik“ [7] a dalších odborných publikacích, které se zabývají štíhlou výrobou nebo tzv. průmyslovým inženýrstvím.

Do báze znalostí bude potřeba vytvořit pravidla, která budou vycházet $\mathrm{z}$ výše uvedené tabulky, která obsahuje otázky na míru zavedení prvků štíhlého podniku, kdy bude nutné ke každému bodu zadat $\mathrm{v}$ expertním systému míru jeho dosažení. V tabulce je slovní vyjádření míry zavedení (existuje/zavádí se/funguje). Konkrétní realizace tohoto problému bude naznačena dále v textu. Místo slovního hodnocení bude použito systému váhových funkcí.

Z výše uvedené tabulky využiji pouze některé body, které se týkají štíhlé výroby. Dále využiji hodnoty základních ukazatelů pro jednotlivé oblasti plýtvání, které se opět týkají výrobních procesů. Abychom mohli plýtvání měřit a postupně odstraňovat, je nezbytné znát hodnoty základních ukazatelů pro jednotlivé oblasti plýtvání. Tabulka níže zachycuje typické hodnoty plýtvání $\mathrm{v}$ našich podnicích $\mathrm{v}$ porovnání s hodnotami nejlepších světových podniků. Ideální je se co nejvíce $\mathrm{k}$ těmto hodnotám postupně přiblížit.

\begin{tabular}{|l|l|l|l|}
\hline Oblast plýtvání & ukazatel & hodnota & Př́čcina plýtvání \\
\hline $\begin{array}{l}\text { Produktivní využití } \\
\text { zařizení }\end{array}$ & OEE/CEZ & $\begin{array}{l}30-50 \% \\
\text { Cíl: 85 } \\
\%\end{array}$ & $\begin{array}{l}\text { Poruchy, čekání na materiál, } \\
\text { přestavování zařízení, práce při } \\
\text { snížených rychlostech, nekvalita }\end{array}$ \\
\hline $\begin{array}{l}\text { Produktivní využití } \\
\text { pracovníka }\end{array}$ & $\begin{array}{l}\text { Procento činností, } \\
\text { které přidávají } \\
\text { hodnotu }\end{array}$ & $\begin{array}{l}30-40 \% \\
\text { Cíl: 70\% }\end{array}$ & $\begin{array}{l}\text { Zbytečné pohyby, hledání nástrojů, } \\
\text { materiálu a informací, čekání, } \\
\text { nedodržování pracovní doby }\end{array}$ \\
\hline $\begin{array}{l}\text { Podíl plýtvání na } \\
\text { průběžné době } \\
\text { výroby }\end{array}$ & VA index & $\begin{array}{l}99-80 \% \\
\text { Cíl 70\% }\end{array}$ & $\begin{array}{l}\text { Zásoby, čekání na skladech, velké } \\
\text { dávky, poruchy, chybějící } \\
\text { komponenty, nefungující zásobování }\end{array}$ \\
\hline
\end{tabular}

Tabulka 2: Typické hodnoty plýtvání v našich podnicích [7]

Z výše uvedené tabulky tedy vyplývají následující dotazy:

- Jaké jsou hodnoty produktivního využití zařízení?

- Jaké je produktivní využití pracovníka?

- Jaký je podíl plýtvání na průběžné době výroby?

Pro další rozšîření báze znalostí lze využít další kritéria štíhlé a efektivní výroby:

- dodržování norem zmetkovosti,

- logistické náklady na jednotku produkce,

- perioda změny technologií,

- perioda výměny strojního zařízení.

V předcházející části byla uvedena základní kritéria, která poslouží pro tvorbu pravidel, na základě kterých bude inferenční mechanismus expertního systému po zadání konkrétních údajů vyhodnocovat míru zavedení principů štíhlé výroby. Báze znalostí se vytváří pomocí NEST editoru a je uložena do XML souboru. Nejprve se zadávají globální parametry báze znalostí. Mezi důležitá nastavení patří zadání rozsahu vah, globálního prahu platnosti kontextu a předpokladu. Je možné definovat také typ inferenčního mechanismu (standardní, 
logický, neuronový nebo hybridní). Dále je možno přidat jméno experta a znalostního inženýra včetně popisu znalostní báze.

Nyní se již zaměřím na samotný princip tvorby báze znalostí pomocí NEST editoru. Základem je definovat atributy a od nich odvozené výroky. Teprve poté mohou být definována pravidla, která jsou složena z daných výroků.

Jako základní atribut zvolím atribut „Štíhlá firma“, který má následující koncové výroky:

- Štíhlá firma (principy neexistují)

- Štíhlá firma (principy se zavádějí)

- Štíhlá firma (principy zavedeny)

Dále je potřebné vytvořit další podstatné atributy a od nich odvozené výroky, které se týkají problematiky štíhlého podniku. Atributy budou vycházet z upravené tabulky „Stupeň zavedení prvků štíhlé výroby“ a budou doplněna o atributy a pravidla produktivity výrobních ploch, plnění plánovaných norem a produktivního využití zařízení. Pro každé pravidlo bude možno zadat hodnot dle váhy $-3,3$. V prrípadě, že je kritérium irelevantní, pak se zadá hodnota váhy rovna nule nebo lze přímo zvolit slovní váhu „irelevantní“. Seznam vytvořených atributů je vidět na níže uvedeném obrázku. Ilustrován je atribut „Štíhlá firma“ včetně jeho koncových výroků.

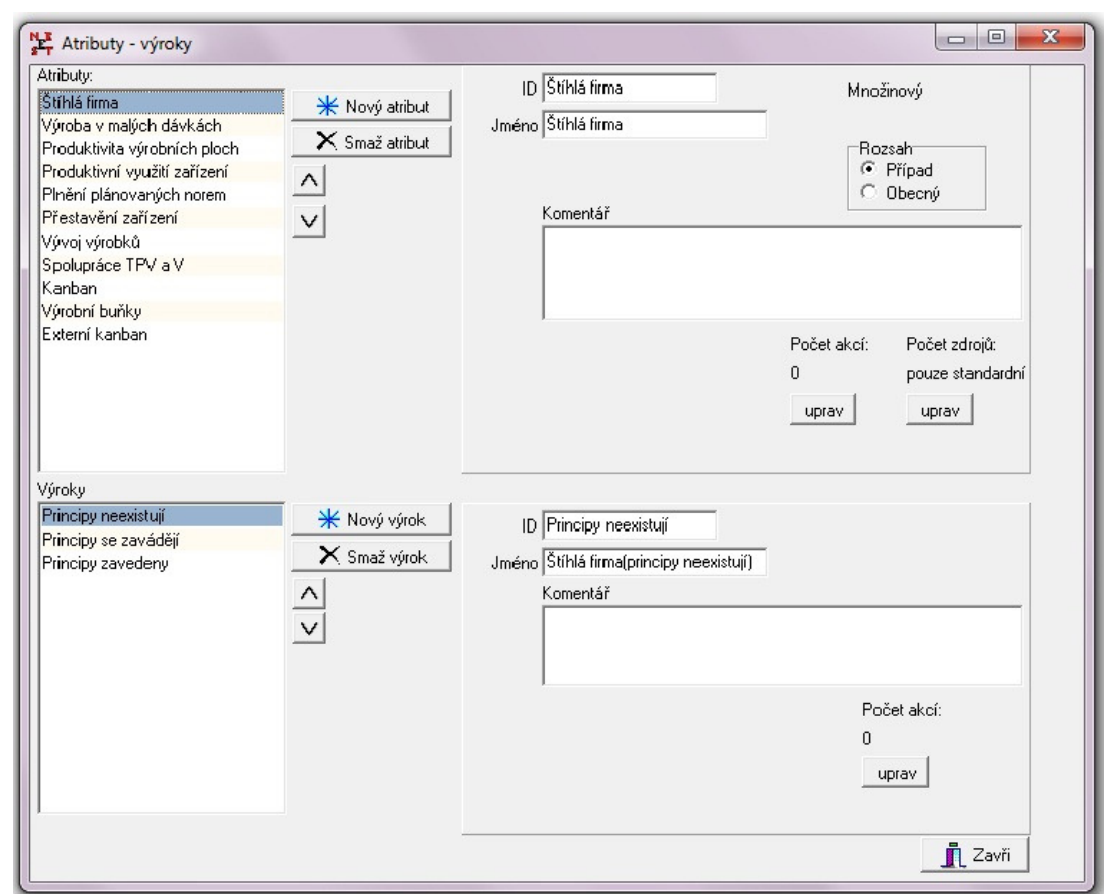

Obrázek 1: Příklad tvorby atributu „Štíhlá firma“ a odvozených výroků v NEST editoru

Na základě výše uvedeného vytvořeného atributu „Štíhlá firma“ a odvozených výroků pomocí NEST editoru je vygenerována v bázi znalostí, která je uložena v XML jazyku př́islušná syntaxe. Na základě definovaných atributů a od nich odvozených výroků je možné následně vytvářet pravidla, která slouží k reprezentaci znalostí ve znalostní bázi expertního systému.

Příklady vytvořených pravidel:

IF Produktivní využití zařízení (vysoké) AND Plnění plánovaných norem (vysoké) THEN Štíhlá firma (Principy zavedeny)[3,000] 
IF Produktivita výrobních ploch (střední) AND Produktivní využití zařízení (střední) AND Plnění plánovaných norem (střední) THEN Štíhlá firma (Principy se zavádějí)[3,000]

IF Kanban AND Externí kanban THEN Štíhlá firma (Principy zavedeny)[2,500], Štíhlá firma (Principy neexistují)[-2,500]

IF NOT (Vývoj výrobků) AND NOT (Výrobní buňky) AND NOT (Spolupráce TPV a V) THEN Štíhlá firma (Principy neexistujî)[3,000]

Pravidla se vytvářejí pomocí NEST editoru a jsou ukládána pomocí XML jazyka. Níže je pro ilustraci uveden prríklad pravidla.

IF Produktivní využití zařízení (vysoké) AND Plnění plánovaných norem (vysoké) THEN Štíhlá firma (Principy zavedeny)[3,000]

Po vytvoření báze znalostí lze provést konzultaci v systému NEST, kdy systém na základě získaných dat o dané firmě posoudí, do jaké míry štíhlosti ve výrobě dosahuje. Prozatím budu vycházet $\mathrm{z}$ fiktivních dat. Před začátkem konzultace je potřeba nahrát bázi dat. Vytvořil jsem bázi dat s názvem Lean company.xml. Poté následuje nastavení parametrů konzultace: typ neurčitosti (standardní, logický, neuronový, hybridní), priorita pravidel (od začátku, od konce, minimální délka, maximální délka, definovaná expertem), implicitní váha (neznámá, irelevantní), způsob odpovídání (dialog, dialog s dotazníkem, dotazník, nahrát odpovědi ze souboru) a typ konzultace (odkládání, bez odkládání). Poté systém zobrazuje postupně jednotlivé dotazy, na které uživatel odpovídá. Na základě získaných odpovědí na dotazy se odvodí podle báze znalostí, která obsahuje znalosti v podobě pravidel, závěrečné výsledky (cílové výroky).

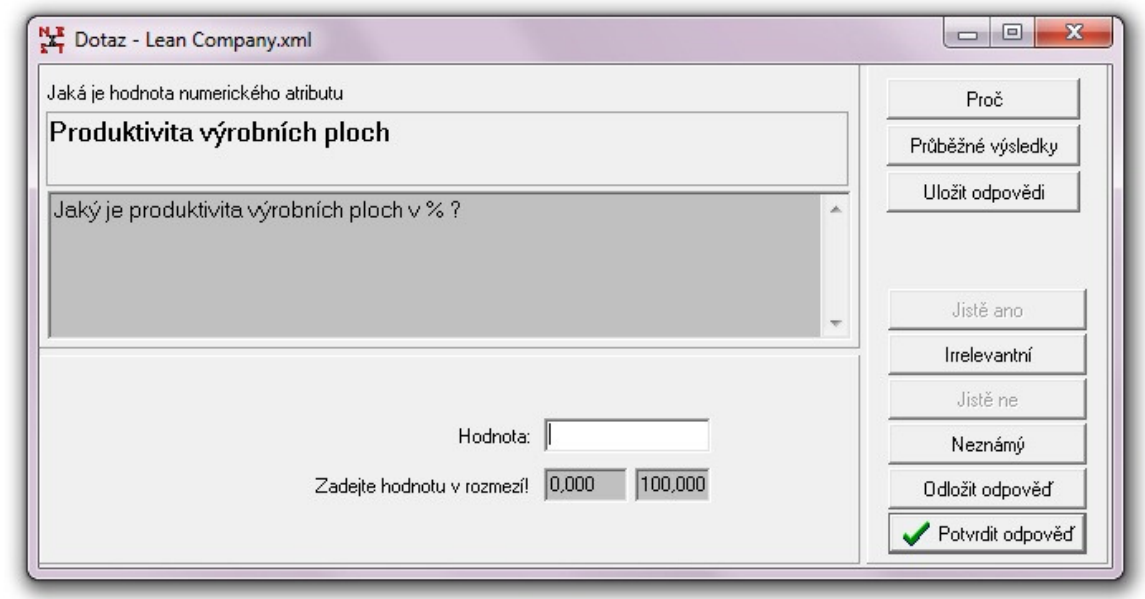

Obrázek 2: Proces konzultace - zadání hodnoty produktivity výrobních ploch

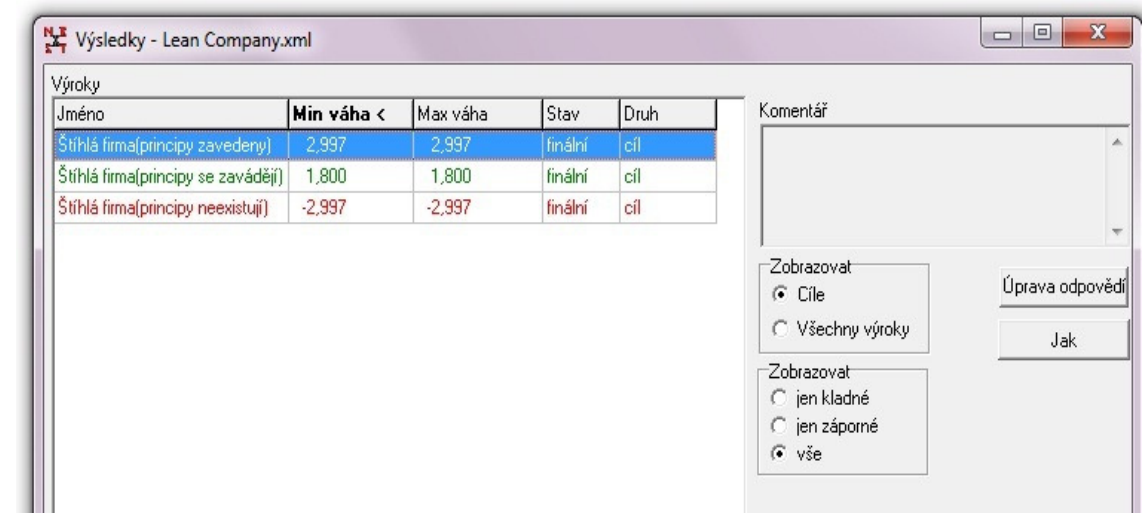

Obrázek 3: Závěrečné vyhodnocení míry zavedení principů štíhlého firmy (výroba) 


\section{Závěr}

Expertní systémy lze využít $\mathrm{v}$ řadě oblastí. Nejinak je tomu $\mathrm{v}$ oblasti vrcholového managementu. Dle mého názoru může být velmi užitečné, když si daná firma provede analýzu toho, zda splňuje kritéria štíhlé výroby. Tuto analýzu může provést na základě konzultací s odborníky, kteří se zabývají problematikou štíhlých firem. Daleko rychlejší a levnější záležitostí by ovšem bylo využít expertního systému, který by byl schopen bezprostředně na základě poskytnutých informací zhodnotit, jak daleko má dané firma k principům štíhlé výroby. Tento přístup by dle mého názoru mohl být $\mathrm{v}$ praxi uplatňován především $\mathrm{v}$ prostředí malých a středních firem.

$\mathrm{V}$ rámci případové studie byla uvedena problematika identifikace míry štíhlosti výroby pomocí expertního systému NEST. Byla vytvořena báze znalostí, na které lze demonstrovat kvalifikované posouzení, zda je výroba štíhlá či nikoliv. Tato báze znalostí je prozatím pouze demonstrační a byla testována na fiktivních datech, které simulovaly vzorové případy štíhlé nebo naopak neštíhlé výroby. Po definitivním dokončení a odladění báze znalostí je plánováno ověření na reálných datech v rámci disertační práce, která se zabývá problematikou Lean Company z pohledu štíhlosti výroby, vývoje, administrativy a logistiky.

\section{Literatura:}

\section{Monografie}

[1] BERKA, P. Tvorba znalostních systémi̊. 1. vyd. Praha: Vysoká škola ekonomická, 1994, 190 s. ISBN 9788070796764.

[2] CARREIRA, B. Lean Manufacturing That Works: Powerful Tools for Dramatically Reducing Waste and Maximizing Profits. 1. vyd. New York: AMACOM, 2005. 295 s. ISBN 0-8144-7237-0.

[3] DAVIS, J. W. Lean Manufacturing: Implementation Strategies that Work. 1. vyd. New York: Industrial Press, 2009. 178 s. ISBN 978-0-8311-3385-6.

[4] DVOŘÁK, J. Expertní systémy. 1. vyd. Brno: Vysoké učení technické v Brně, 2004, $92 \mathrm{~s}$.

[5] GÁlA, L., POUR, J., TOMAN, P. Podniková informatika. 2. vyd. Praha: Grada Publishing, 2009. 496 s. ISBN 978-80-247-2615-1.

[6] IVÁNEK, J., KEMPNÝ, R., LAŠ, V. Znalostní inženýrství 1. vyd. OPF Karviná. 2007, $125 \mathrm{~s}$.

[7] KOŠTURIAK, J., FROLÍK, Z. Štíhlý a inovativní podnik. 1. vyd. Praha: Alfa Publishing, 2006. 237 s. ISBN 80-86851-38-9.

[8] TVRDÍKOVÁ, M. Aplikace moderních informačních technologií v řízení firmy. 1. vyd. Praha: Grada Publishing, 2008. 176 s. ISBN: 978-80-247-2728-8.

[9] WILSON, L. How To Implement Lean Manufacturing. 1. vyd. New York: McGraw-Hill Prof Med/Tech, 2009. 336 s. ISBN 9780071625074.

\section{Elektronické zdroje}

[10] CELBOVÁ, I. Úvod do problematiky expertních systémů. Url: http://www.ikaros.cz/uvod-do-problematiky-expertnich-systemu

[11] LAŠ, V. Popis systému NEST. Url: http://vladalas.info/nest/popis.aspx

[12] LAŠ, V. Reprezentace znalostí. Url: http://vladalas.info/nest/reprezentaceZnalosti.aspx

\section{JEL C88, D83}




\section{Ing. Radim Dolák}

student doktorského studia Katedry informatiky

Obchodně podnikatelská fakulta v Karviné

Slezská univerzita v Opavě

Univerzitní náměstí 1934/3, 73340 Karviná

dolak@opf.slu.cz 